\title{
10 Bobby Sands ${ }^{32}$
}

Bobby Sands was a member of the Irish Republican Army in Northern Ireland and was imprisoned by the British courts for his activities. He went on hunger strike while in prison and died in H Block of HMP Maze (Long Kesh) prison on May $5^{\text {th }} 1981$ at the age of 27. Bobby Sands was born in 1954 in Rathcode, a predominantly loyalist district of north Belfast. As a result of his final arrest and imprisonment, he was sentenced in September 1977 to fourteen years. He was denied the category of "political prisoner" and imprisoned instead as an "ordinary prisoner." The prisoners so labeled protested this action in various ways (such as refusing to wear the prison uniform), until some of the prisoners decided to go on a hunger strike. The second hunger strike started on March $1^{\text {st }} 1981$, and Bobby Sands died on the $66^{\text {th }}$ day of his hunger strike, on May $5^{\text {th }}$. He kept a diary for the first 17 days of his hunger strike (Sands, 1998), and the present study analyzed his diary using the LIWC program.

Two points must be made here. Bobby Sands did not die in the same way as the other individuals discussed in this section. His goal was not to die, but rather to protest the treatment of IRA prisoners by the British courts. However, he was aware that his death was possible, if not likely, and his actions did indeed result in his death. Whether martyrs are "suicides" or not is a matter of debate which illustrates the absence of a good nomenclature for labeling self-induced deaths.

Second, the diary of Bobby Sands diary ends before his death. This was true of Katie's diary also, although her diary ended only ten days before her death. Researchers may wonder how the content of the diary might have changed had it extended up to the day of death but, in the cases of Katie and Bobby Sands, we cannot know.

\subsection{The LIWC Analysis}

The 17 entries in the diary of Bobby Sands were analyzed by the LIWC program. The entries were numbered from 1 to 17, and Pearson correlation coefficients were calculated between the entry number and each of the 74 content variables in order to identify linear trends over the 17 days. The results are shown in Table 10-1. Of the 74 variables examined, six correlation coefficients were statistically significant, and a further seven were close to statistical significance.

In the earlier study of Katie's diary, Pennbaker and Stone (2004) found an increase in positive emotions as the day of Katie's death came closer. The same increase in positive emotions was found in the diary of Bobby Sands, as well as an increase in positive feelings. As with Katie's diary, there was a decrease in words concerned with death over time in the diary of Bobby Sands. This result is consistent with the study

32 I would like to thank John Connolly for stimulating this chapter and for buying the published diary for me. 
Tab. 10.1: Correlations over the last 17 days of Bobby Sands' life (numbered 1-17)

\begin{tabular}{|c|c|}
\hline & Pearson $\mathrm{r}$ \\
\hline Total second person & $0.45 \#$ \\
\hline Articles & $0.47 \#$ \\
\hline Prepositions & $0.45 \#$ \\
\hline Numbers & $-0.48^{\star}$ \\
\hline Positive emotions & $0.54^{\star}$ \\
\hline Positive feelings & $0.48 \#$ \\
\hline Cognitive processes & $-0.43 \#$ \\
\hline Inhibition & $-0.65^{* *}$ \\
\hline Seeing & $0.41 \#$ \\
\hline Metaphysical issues & $-0.52^{\star}$ \\
\hline Religion & $-0.47 \#$ \\
\hline Death & $-0.45 \#$ \\
\hline Physical states & $0.49^{*}$ \\
\hline Eating & $0.75^{\star \star}$ \\
\hline
\end{tabular}

by Spiegel and Neuringer (1963), which I have cited many times already in this book, who speculated that the suicide notes of completed suicides would avoid mentioning words associated with death and suicide since there would be tendency to avoid thinking of the act they were about to choose. In a comparison of genuine and simulated suicide notes, the genuine notes did have fewer mentions of suicide. The diaries of both Katie and Bobby Sands had a decline in death-related words over time as the time of their death came closer.

As the diary of Bobby Sands progressed, there was an increase in concern with his physical state and with eating, as might be expected in someone who was engaged in a hunger strike. Some of the changes identified in Katie's diary (changes in personal pronouns, social words, negative emotions, and question marks) were not found in the diary of Bobby Sands. In addition, whereas there was an increase in religious words over time in Katie's diary, religious words declined over time in the diary of Bobby Sands.

Several unique findings were identified in the diary of Bobby Sands over time. There were decreases in words concerned with metaphysical issues and with inhibition (such as "block" and "constraint") and a trend toward fewer words concerned with cognitive processes (such as "cause” and "know").

The results of this analysis of the diary of Bobby Sands during his hunger strike that resulted in his death show some similarities to previous studies of the diary of a young woman who died by suicide, but also some differences. The differences are to be expected since, not only was the intent of Bobby Sands not to kill himself but rather to make a political protest, but also because each individual is unique in the psychodynamics of their behavior. 